http://jmscr.igmpublication.org/home/ ISSN (e)-2347-176x ISSN (p) 2455-0450 crossref DOI: https://dx.doi.org/10.18535/jmscr/v7i9.25

\title{
CT Guided FNAC (Fine Needle Aspiration Cytology) is Excellent Diagnostic Methods for the Diagnosis of Thoracic Mass Lesions in Tertiary Care Hospital at Muzaffarpur, Bihar
}

\author{
Authors \\ Dr Manoj Kumar ${ }^{1}$, Dr Prahalad Sharma ${ }^{2 *}$ \\ ${ }^{1}$ Professor and H.O.D., Department of Pathology, S. K. Medical College, Muzaffarpur \\ ${ }^{2}$ Assistant Professor, Department of Pathology, S. K. Medical College, Muzaffarpur \\ *Corresponding Author \\ Dr Prahalad Sharma \\ Assistant Professor, Department of Pathology, S.K. Medical College, Muzaffarpur
}

\begin{abstract}
Objective: The aim of present study was to evaluate the role of CT guided FNAC as diagnostic and supportive investigation for the diagnosis of thoracic mass lesions.

Material and Methods: A total of 40 patients of different age groups of both sexes with presentation of thoracic mass lesions were referred from medical and surgical OPD for CT guided FNAC in our department were included in the study. After thorough clinical history, all the patients were subjected to proper clinical examination. Prior to F.N.A.C. all the relevant routine investigation (CBC, ESR, LFT, $K F T, B T, C T$, Blood Sugar, Viral Markers) were performed and written consent were taken. The transthoracic approach with the patient in supine, prone or decubitus position was used. Aspiration was done by commercially available 20 Gauze, $88 \mathrm{~mm}$ long spinal needle. Specimens were immediately smeared on glass slides and air dried for May Grunwald Giemsa stain. Wet fixed smears were stained by Papanicolaou and H\&E stains and seen under oil immersion lens.

Results: Out of 40 patients, 32 patients (80\%) were males and 8 patients (20\%) were females. The age of the patients ranges from 10 years to 75 years. Pulmonary lesion was present in 30 patients (75\%) which was the most common site of intrathoracic lesions, 6 patients (15\%) had mediastinal lesion whereas 4 patients (10\%) had pleural involvement. Almost all the lung tumors were malignant, out of which squamous cell carcinoma has got the highest incidence (25\%).

Conclusion: Computed Tomography Guided Fine Needle Aspiration cytology is a simple, safe, highly sensitive and specific procedure with high diagnostic accuracy for diagnosis of intrathoracic mass lesions. The diagnostic sensitivity for malignancy was $97 \%$ and specificity 100\%. Though our priority was cytological assessment, the cytological diagnosis was corroborated with clinico-radiological parameters and transbronchial biopsies whenever applicable.
\end{abstract}

Keywords: Transthoracic, CT guided FNAC, Lungs, Mediastinum.

\section{Introduction}

Computed Tomography (CT) guided transthoracic

Fine Needle Aspiration Cytology (FNAC) has gained immense popularity in recent times and has been in use for evaluation of suspicious thoracic space occupying lesions. This interventional 
procedure picked up further momentum with the rapid advancement in the field of radiology and imaging.

This percutaneous guided procedure has not only decreased the number of diagnostic modalities which are invasive in nature but also offers quick and accurate diagnosis. Secondly, optimal characterization of tumor type is of paramount importance for chemotherapy and radiotherapy afterwards. Moreover, CT defines the relationship of the needle to the surrounding vital tissues. Once the needle tip is demonstrated by CT, its precise position is ensured.

J.P. Singh et al in 2004 conducted transthoracic FNAC in 34 patients and opined that early diagnosis of thoracic lesions offers opportunity for either cure or expeditious treatment.

Often the asymptomatic pulmonary acinar nodules pose great difficulties to the detriment of the patient. Many of these lesions are basically benign and inflammatory in nature, CT guided FNAC can be a perfectly applicable gesture here.

A study of 114 cases of trans-thoracic lung FNAC by K.B. Tan et al in 1997 to1999 revealed that accurate sub-classification of bronchogenic carcinoma was possible in vast majority of malignancies in the right clinical contexts.

The aims and objectives of our study was to evaluate the role of CT guided FNAC in early diagnosis of thoracic lesions, confirmation of clinically unresectable neoplasms, detection of metastatic lesions wherever possible and to ascertain histogenesis.

\section{Materials and Methods}

Present study was conducted in the Department of Pathology, Sri Krishna Medical College, Muzaffarpur, with the help of Department of Medicine, Surgery, Pediatrics and Radiology,

\section{During the period of January 2016 to} December 2017.

This was a prospective study, where the results of CT guided FNAC of thoracic lesions had been evaluated. A total of 40 patients, with different presenting complains and with thoracic mass lesions were seen in Medicine, Surgery and Pediatrics OPD were send for CT Guided F.N.A.C. in our department. From all the patient thorough present or past medical and surgical history were taken. Proper clinical examination was done. All the relevant routine investigation was performed in every case (CBC, ESR, BT, CT, LFT, KFT, Blood Sugar, Viral markers and plain $\mathrm{X}$-Ray abdomen etc). Written consent was taken from all the patients. Before to perform F.N.A.C. it is mandatory to inform the patients and explain them about the procedure.

The transthoracic approach with the patient in supine, prone or decubitus position was used. The site of aspiration was relocated on a series of sections at levels preselected from the initial diagnostic study. The distance from the midline to the entry site, the depth from the skin to the lesion and the angle of insertion of the needle were measured on the CT monitor console.

The skin was cleansed with povidone iodine and the area was sterilely draped. Once the needle was placed, a scan was obtained to verify position, until the needle tip was shown to be inside the lesion. When included within the scan slice, the needle tip appeared square and the needle had a uniform density throughout its length. Aspiration was done by commercially available 20 Gause, 88 $\mathrm{mm}$ long spinal needle. Specimens were immediately smeared on glass slides and air dried for May Grunwald Giemsa stain. Wet fixed smears were stained by Papanicolaou and H\&E stains and seen under oil immersion lens. Records of clinical and radiological data are as well as previous or follow up biopsies, if available, were corroborated. Some of the lesions that had discordant clinical outcome were reviewed.

\section{Results}

Out of 40 patients, 32 patients $(80 \%)$ were males and 8 patients $(20 \%)$ were females. The age of the patients ranges from 10 years to 75 years. Pulmonary lesion was present in 30 patients (75\%) which was the most common site of intrathoracic lesions, 6 patients $(15 \%)$ had 
mediastinal lesion whereas 4 patients $(10 \%)$ had pleural involvement. Almost all the lung tumors were malignant, out of which squamous cell carcinoma has got the highest incidence (25\%). We found one bronchioloalveolar carcinoma which was included in adenocarcinoma category. Though it was very difficult to diagnose secondary's with emphasis, all the two cases obtained were representatively similar to primary ones. Lymphoproliferative disorders have the highest prevalence rate. Only a few pleural lesions were obtained amongst which a single case of mesothelioma were present and rest were inflammatory in nature. Most of the cases were inflammatory in nature. Quite a few cases were classified as unsatisfactory, which included smears with low cellular yield.

Table-1 shows total No. of patients with Intrathoracic mass lesion.

\begin{tabular}{|l|c|c|}
\hline Sex & $\begin{array}{c}\text { Total No. of patients with } \\
\text { Intrathoracic mass lesion }\end{array}$ & Percentage \\
\hline Male & 32 & 80 \\
\hline Female & 8 & 20 \\
\hline Total No. of Patients & 40 & $100 \%$ \\
\hline
\end{tabular}

Table-2 shows total number of patients with intrathoracic mass in different age group.

\begin{tabular}{|l|c|c|}
\hline Age group in Year & $\begin{array}{c}\text { Total No. of Patients } \\
\text { with Intrathoracic mass }\end{array}$ & Percentage \\
\hline $10-40$ & 10 & 25 \\
\hline $41-70$ & 26 & 65 \\
\hline $71-75$ & 4 & 10 \\
\hline
\end{tabular}

Table-3 shows Site of Intrathoracic mass Lesion

\begin{tabular}{|l|c|c|}
\hline $\begin{array}{l}\text { Location of } \\
\text { Intrathoracic Lesion }\end{array}$ & Total No. of Patients & Percentage \\
\hline Pulmonary (Lungs) & 30 & 75 \\
\hline Pleura & 4 & 10 \\
\hline Mediastinal & 6 & 15 \\
\hline
\end{tabular}

Table-4 Shows common Clinical feature of Patients

\begin{tabular}{|l|c|c|}
\hline Symptoms of Patients & $\begin{array}{c}\text { No. of Patients with } \\
\text { intrathoracic Lesion }\end{array}$ & Percentage \\
\hline Cough & 22 & 55 \\
\hline Weight loss & 25 & 62.5 \\
\hline Loss of Appetite & 28 & 70 \\
\hline Hemoptysis & 14 & 35 \\
\hline Chest Pain & 13 & 32.5 \\
\hline Fever & 12 & 30 \\
\hline Dyspnea & 11 & 27.5 \\
\hline Asymptomatic & 2 & 5.26 \\
\hline
\end{tabular}

Table-5 shows of Routine tests Findings of patients.

\begin{tabular}{|l|c|c|}
\hline $\begin{array}{l}\text { Tests done of patients with } \\
\text { Intrathoracic Lesion prior } \\
\text { to CT guided FNAC }\end{array}$ & Finding & $\begin{array}{c}\text { No. Patients with } \\
\text { Percentage. }\end{array}$ \\
\hline Chest X-ray & $\begin{array}{c}\text { Abnormal Chest } \\
\text { X-ray in all the } \\
\text { patient }\end{array}$ & $40(100 \%)$ \\
\hline Total WBC Count & Increase & $18(45 \%)$ \\
\hline ESR & Increase & $22(55 \%$ \\
\hline
\end{tabular}

Table-6 Shows CT-Guided FNAC diagnosis of Patient with Intrathoracic Lesion.

\begin{tabular}{|c|c|c|c|c|}
\hline $\begin{array}{l}\text { Total No. } \\
\text { of Patients } \\
\text { underwent } \\
\text { CT-guided } \\
\text { FNA }\end{array}$ & $\begin{array}{l}\text { Type } \\
\text { Lesion } \\
\text { Diagnosed }\end{array}$ & Cytological finding & $\begin{array}{c}\text { No. of } \\
\text { Patie } \\
\text { nts }\end{array}$ & Percentage \\
\hline \multirow[t]{9}{*}{$\mathrm{n}=40$} & \multirow{5}{*}{$\begin{array}{l}\text { Malignant } \\
\mathrm{n}=21 \\
(52.5 \%)\end{array}$} & Adenocarcinoma & 6 & 15 \\
\hline & & $\begin{array}{c}\text { Squamous Cell } \\
\text { carcinoma }\end{array}$ & 10 & 25 \\
\hline & & $\begin{array}{c}\text { Small Cell } \\
\text { carcinoma }\end{array}$ & 02 & 5 \\
\hline & & $\begin{array}{l}\text { Large Cell } \\
\text { carcinoma }\end{array}$ & 01 & 2.5 \\
\hline & & $\begin{array}{c}\text { Metastatic } \\
\text { carcinoma } \\
\text { (Renal cell } \\
\text { carcinoma and } \\
\text { Colonic } \\
\text { Adenocarcinoma) } \\
\end{array}$ & 02 & 5 \\
\hline & \multicolumn{2}{|c|}{ Benign Lesions } & 03 & 7.5 \\
\hline & \multicolumn{2}{|c|}{$\begin{array}{c}\text { Inflammatory/ Granulomatous } \\
\text { Lesion }\end{array}$} & 09 & 22.5 \\
\hline & \multicolumn{2}{|c|}{$\begin{array}{c}\text { Atypical (Reactive atypia / } \\
\text { Dysplasia) }\end{array}$} & 04 & 10 \\
\hline & \multicolumn{2}{|c|}{$\begin{array}{l}\text { Undiagnosed due to inadequate } \\
\text { tissue. }\end{array}$} & 03 & 7.5 \\
\hline
\end{tabular}

\section{Discussion}

Amongst 40 patients studied, only 1 patients in pediatric age group were found, all of whom were diagnosed as non Hodgkin's lymphoma. Ironically, the oldest patient, 75 years old, had pericardial effusion along with a lung lesion of tuberculous etiology.

In our study, males (80\%) were grossly preponderant in comparison to females (20\%). K.B. Tan el al study in 1997-99 also reveals that the males $(71.1 \%)$ outnumbered the females (28.9\%).

The incidence of lung lesions was $75 \%$ among all thoracic lesions which corroborated well with other international studies. Though the incidence of squamous cell carcinoma was highest $(25 \%$ of all thoracic lesions), the prevalence of adenocarcinoma (15\%) trailed behind very closely. On the contrary, studies by Gouliamos 
and Rajwanshi found relatively higher percentage of large cell carcinomas. But international figures have shown almost equal incidences of primary lung squamous cell carcinoma and adenocarcinoma.

However, this may just reflect the overall differences in the frequency of specific lung cancer types in different studies.

Powers et al reported a large multi-institutional study of mediastinal lesions where metastatic small cell carcinoma was the commonest neoplasm followed by lymphoma, but nonHodgkin's lymphoma was found to be commonest in our series.

Several authors pointed out the lack of absolute criteria to differentiate between primary and metastatic lung tumors. But in any sample, a background of necrosis in the presence of well differentiated carcinoma is unlikely of a primary one.

In our study, 2 metastatic malignancies namely a renal cell carcinoma, and a colonic adenocarcinoma were diagnosed with reasonable confidence as they were look likes of the primaries.

One case of mesothelioma in a 40 years old female needs special mention among pleural lesions though the relationship with asbestosis could not be established. WHO classification of 1999 was adopted while describing the prevalence of lung tumors, but for practical purposes the classification into small cell and non small cell categories is often satisfactory and can be accomplished in majority of the cases.

The atypical hyperplasia dysplasia sequence in bronchial epithelium is represented in FNAC by a range of cytological appearances. Atypical squamous metaplasia and dysplasia presents as small sheets of squamous cells with nuclear pleomorphism and hyperchromasia, but without bizarre cell configuration or fully developed nuclear criteria of carcinoma. We found 4 cases of reactive atypia and dysplasia in our series. The diagnostic sensitivity for malignancy was $97 \%$ and specificity $100 \%$.

\section{Conclusion}

With the availability of modern methods, CT guided FNAC could be an optimum modality for the diagnosis of thoracic lesions, which has great impact on patient management consequently.

\section{References}

1. Fraire A E, MC Larty J W, Greenberg S Ds. Changing utilization of cytopathology versus histopathology in the diagnosis of lung cancer. Diagnosis of Cytopathology 1991;7:359-62.

2. J P Singh, L Garg, V Setia. Computed Tomography (CT) guided transthoracic needle aspiration cytology in difficult thoracic mass lesions not approachable by USG. Ind J Radiology Imaging 2004; 14(4):395-400.

3. Meziane M A, Hruban R H, Zerhouni E A et al. High resolution CT of the lung parenchyma with pathologic correlation. Radiographics1988; 8:27-54.

4. K B Tan, T P Thamboo, S C Wang, Barbro Nilsson, A Rajwanshi, M SaltoTellez. Audit of transthoracic fine needle aspiration of the lung: Cytological sub classification of bronchognic carcinomas and diagnosis of tuberculosis. Singapore Med J 2002; 43(11):570-75.

5. WHO Histological typing of lung and pleural tumors. World Health Organisation International Classification of Tumors. Berlin: Springer, 1999.

6. Gouliamos AD, Giannopoulos DH, Panagi GM, Fletoridis NK, Deligeorgi-Politi HA, Vlahos IJ. Computed tomography- guided fine needle aspiration of peripheral lung opacities: an initial diagnostic procedure. Acta Cytol 2000; 44:344-8.

7. Rajwanshi A, Jayaram N, Behera D, Gupta SK, Malik SK. Fine needle aspiration cytology of intrathoracic lesions-A repraisal. Indian J Pathol Microbio1 1989; 32:306-9. 
8. Powers CN, Silverman JF, Geisinger KR, Frable WJ. Fine needle aspiration biopsy of the mediastinum: a multi institutional analysis. Am J Clin Patho 1996; 105:16873.

9. Celeste NP. Respiratory Cytopathology. In: Barbara F, Atkinson JFS, eds. Atlas of difficult diagnosis in cytopathology. 1ed. W B Saunders Company, 1998:113-144.

10. Greg S, Felicity F,Darrel W. Tumors of lung and mediastinum. In: Gray W, Mckee GT, eds. Diagnostic Cytopathology. 2nd ed. Churchill Livingstone, 2003:71-131. 